\title{
AUTONOMIA PRIVADA E REgULAÇÃO ESTATAL NOS PROCEDIMENTOS ADMINISTRATIVOS DE AUTORIZAÇÃO DAS INSTITUÇÕES DE ENSINO SUPERIOR
}

\author{
Privet AUTONOMY AND ESTATE REgUlATE IN THE ADMINISTRATIVE PROCEDURES OF \\ AUTHORIZATION OF THE INSTITUTIONS OF HIGHER EDUCATION \\ AUTONOMÍA PRIVADA Y REGULACIÓN ESTATAL EN LOS PROCEDIMIENTOS \\ ADMINISTRATIVOS DE AUTORIZACIÓN DE LAS INSTITUCIONES DE ENSEÑANZA SUPERIOR
}

Magno Federici Gomes ${ }^{1}$

\section{Resumo}

Objetiva-se, com o presente trabalho, o estudo dos atos administrativos e seus respectivos procedimentos de autorização, reconhecimento de cursos superiores, credenciamento e recredenciamento de Instituições de Ensino Superior (IES), do sistema federal de ensino. Este artigo é preponderantemente teórico-documental, sob uma perspectiva dogmática, empregada como forma de análise dos resultados. Como conclusão, apresentou-se a natureza jurídica dos atos administrativos autorizativos, a obrigatoriedade do respeito aos princípios constitucionais processuais nos procedimentos administrativos, a íntima relação entre os primeiros e o Sistema Nacional de Avaliação da Educação Superior (SINAES), bem como a ilegalidade parcial do art. 11 do Decreto $\mathrm{n}^{\circ}$ 5.622/05.

Palavras-chave: Políticas públicas educacionais. Avaliação de sistemas educacionais. Atos administrativos de autorização de instituições de ensino superior.

\section{INTRODUÇÃO}

Objetiva-se, com o presente trabalho, o estudo dos atos administrativos de autorização, reconhecimento de cursos superiores, credenciamento e recredenciamento de Instituições de Ensino Superior (IES), do sistema federal de ensino, existentes no ordenamento infraconstitucional e em atos normativos ${ }^{2}$, tudo sob o prisma da Constituição da República brasileira de $1988(\mathrm{CR} / 88)$.

O ensino superior foi reconfigurado diversas vezes, dentro do sistema educacional brasileiro. Assim, coloca-se em relevo "a instalação de uma tipologia variada de

\footnotetext{
${ }^{1}$ Pós-doutor em Direito Público e Educação pela Universidade Nova de Lisboa-Portugal, com apoio CAPES. Pós-doutor em Direito Civil e Processual Civil, Doutor em Direito, Mestre em Direito Processual e Especialista em Direito, pela Universidad de Deusto-Espanha. Mestre e Especialista em Educação pela PUC Minas. Graduado em Direito pela PUC Minas. Coordenador do curso de Direito da Faculdade Arnaldo Janssen. Docente do Mestrado Acadêmico em Direito e Atividade Negocial do Centro Universitário UNA MG. Professor Adjunto da PUC Minas, na graduação e especialização. Advogado. Tem experiência nas áreas de Direito e Educação, com ênfase em Direito Processual e Políticas Públicas Educacionais, atuando principalmente nas seguintes linhas: direito processual civil, direito constitucional e avaliação de Instituições de Ensino Superior. É autor de livros e artigos jurídicos e educacionais.

2 "Atos administrativos normativos são aqueles que contêm um comando geral do Executivo, visando à correta aplicação da lei. O objetivo imediato de tais atos é explicitar a norma legal a ser observada pela Administração e pelos administrados. Esses atos expressam em minúcia o mandamento abstrato da lei, e o fazem com a mesma normatividade da regra legislativa, embora sejam manifestações tipicamente administrativas. A essa categoria pertencem os decretos regulamentares e os regimentos, bem como as resoluções, deliberações" [...]
} 
estabelecimentos com características institucionais e práticas acadêmicas bastante diferenciadas" (SOUSA, 2003, p. 12). A referida situação adiciona elementos à relação entre os setores público e privado. Pode-se basear:

[...] em contextos sociais diversos e particularizados. O ensino superior brasileiro possui vários cenários que expressam uma pluralidade, tanto do ponto de vista da natureza quanto da dependência administrativa das instituições que o compõem. Tal realidade demanda estudos que tratem esse grau de ensino em sua heterogeneidade, visando questionar o discurso de sua suposta homogeneidade, pretensamente ideologizado. Em um contexto no qual há diferenças de interesses, demandas e organizações internas, o discurso da "universidade brasileira" é, portanto, questionável. (SOUSA, 2003, p. 12).

Em tal conjuntura, a expressão universidade brasileira deve ser empregada com cuidado, pois serve "para designar centros de ensino e produção original de conhecimentos, mas também para se referir à totalidade de um complexo sistema" (SOUSA, 2003, p. 12). Em sentido equivalente, comenta-se que, no Brasil, "o ensino superior não esteve tradicionalmente organizado com base na universidade" (RIBEIRO, 2002, p. 17), tendo sido "marcado pelo crescimento do número de escolas isoladas" (RIBEIRO, 2002, p. 19; no mesmo sentido MURIEL, 2006, p. 47).

Trigueiro (2000) e Sousa (2003) demonstram que considerar uma parte como o todo produz travas à assimilação das freqüentes alterações nas IES, em processo de crescimento e expansão. Ademais, tal fato omite a diversa realidade de IES com vocações e situações geográficas completamente distintas. Portanto, a evolução do ensino superior brasileiro é campo acadêmico complexo, rodeado por uma grande heterogeneidade de instituições, cada qual dotada de peculiaridades e características próprias, tanto nas redes pública quanto privada. Nesse sentido:

[...] a observação mais óbvia que se pode fazer sobre o universo das IES particulares é a de sua profunda heterogeneidade, sobretudo, como ficou demonstrado, no segmento das IES isoladas. Sob a vala comum dessa denominação, entram Instituições de natureza totalmente distintas, assim como diferentes no porte, tipo e objetivos. As generalizações neste universo, portanto, tornam-se perigosas, difíceis e desaconselháveis e, conseqüentemente, as imagens formadas são freqüentemente distorcidas dependendo do prisma com que são vistas as IES (TRAMONTIN; BRAGA, 1984, p. 38; em sentido equivalente MARTINS, 1981, p. 199-200; TRIGUEIRO, 2000, p. 18-19 e 97-101).

Dessa forma, é necessário apresentar classificações adequadas a um ensino superior tão diverso e heterogêneo quanto o brasileiro, recorrendo-se, em parte, aos ensinamentos de

(MEIRELLES, 1997, p. 161; no mesmo sentido DI PIETRO, 2004, p. 184 e 216; CAUPERS, 2000, p. 207209).

Revista da Faculdade Mineira de Direito, v.12, n. 23, jan./jun. 2011 - ISSN 1808-9429. 
Sampaio (2000), Minto (2006) e Muriel (2006), com tal finalidade. Entre as inúmeras distinções constantes na educação superior do Brasil, quando se tem em vista as categorias do público e do privado, uma instituição pode se diferenciar de outra em vários aspectos formais. Quanto à natureza institucional ou administrativa, as IES podem se classificar como universidades, centros universitários, faculdades integradas ou estabelecimentos isolados. Quanto à sua dependência administrativa, podem ser públicas (federais, estaduais e municipais) ou privadas (art. 19 Lei de Diretrizes e Bases da Educação Nacional - LDB - Lei $n^{\circ}$ 9.394, de 20 de dezembro de 1996). Quando privadas e com relação à constituição jurídica de sua mantenedora, classificam-se como fundações, associações civis ou sociedades civis de direito privado. Quanto aos fins das instituições privadas, elas podem ser lucrativas ou não. Quanto à composição dos membros das instituições, são particulares em sentido estrito,

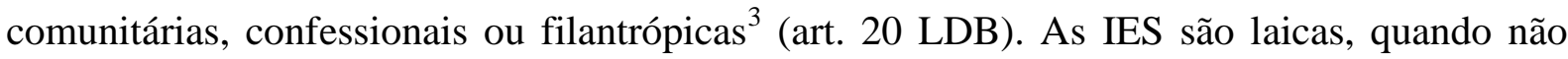
atendem à orientação confessional. Quanto à organização acadêmica, podem ofertar cursos, graduações e pós-graduações, possuindo ou não atividades de extensão e pesquisa. Por fim, podem levar em consideração ou não a titulação do corpo docente.

No que tange aos critérios de diferenciação supracitados, cabe ressaltar que o conceito de universidade pode ser encontrado na LDB, no art. 52. Assim, as universidades são instituições pluridisciplinares que formam pessoas em nível superior, atuam em pesquisas, atividades de extensão, trabalhando o conhecimento humano. De maneira que oferecem, de forma regular, "atividades de ensino, de pesquisa e de extensão" (art. $8^{\circ}$, do revogado ${ }^{4}$ Decreto $\mathrm{n}^{\mathrm{o}} 3.860$, de 09 de julho de $2001^{5}$ ). Acrescenta-se que a universidade "é constituída

\footnotetext{
${ }^{3}$ Salienta-se que as IES filantrópicas são aquelas formadas por grupos que se vinculam à alguma causa humanitária.

${ }^{4}$ Coloca-se de manifesto que o Decreto $n^{\circ} 3.860 / 01$, foi revogado, parcial e totalmente, pelos Decretos $n^{\circ} 4.914$, de 11 de dezembro de 2003; 5.225, de $1^{\circ}$ de outubro de 2004; 5.773, de 09 de maio de 2006; e 5.786, de 24 de maio de 2006, respectivamente. Contudo, como os posteriores atos administrativos normativos, antes mencionados, não apresentaram os elementos identificadores das universidades, faculdades integradas e estabelecimentos isolados, buscou-se no decreto antigo tais dados.

Destaca-se que o Projeto de Lei de Reforma Universitária, em seu art. $9^{\circ}$ dispôs que: "as instituições de ensino superior, quanto à sua organização e prerrogativas acadêmicas, podem ser classificadas como: universidades; centros universitários; ou faculdades" (BRASIL; MEC; MF; MP; MCT, 2006). No mesmo projeto, o art. 12 define as condições para que as IES sejam universidades, o art. 16 os requisitos dos centros universitários e o art. 18, caput e parágrafo único, delineia as faculdades, inclusive integradas.

${ }^{5}$ Decreto $\mathrm{n}^{\mathrm{o}}$ 3.860/01 (revogado): Art. $8^{\circ}$ - As universidades caracterizam-se pela oferta regular de atividades de ensino, de pesquisa e de extensão, atendendo ao que dispõem os arts.52, 53 e 54 da Lei n ${ }^{\circ}$ 9.394, de 1996.

$\S 1^{\circ}$ As atividades de ensino previstas no caput deverão contemplar, nos termos do art. 44 da Lei 9.394, de 1996, programas de mestrado ou de doutorado em funcionamento regular e avaliados positivamente pela Coordenação de Aperfeiçoamento do Pessoal de Nível Superior - CAPES.

$\S 2^{\circ}$ A criação de universidades especializadas, admitidas na forma do parágrafo único do art. 52 da Lei $\mathrm{n}^{\circ}$ 9.394, de 1996, dar-se-á mediante a comprovação da existência de atividades de ensino e pesquisa, tanto em áreas básicas como nas aplicadas, observado o disposto neste artigo.
}

Revista da Faculdade Mineira de Direito, v.12, n. 23, jan./jun. 2011 - ISSN 1808-9429. 
por um conjunto de unidades (centros, institutos, faculdades, departamentos, laboratórios e núcleos). Confere graus, diplomas e títulos como os de bacharel, licenciado, especialista, mestre e doutor" (CAMPOS; MACHADO, 2000, p. 350-351).

Os centros universitários, por sua vez, são IES pluricurriculares, caracterizadas pela extrema qualidade no ensino ofertado, mediante comprovação prévia nas avaliações do Ministério da Educação (MEC), qualificação privilegiada dos docentes e pelas excelentes condições dos trabalhos acadêmicos fornecidos à sociedade. Possuem autonomia universitária para criar, organizar e extinguir cursos de ensino superior e programas de educação de mesmo nível, estendendo ou remanejando vagas nos que já existem, desde que o façam em sua sede institucional (arts. $1^{\circ}$ e $2^{\circ}$ Decreto $n^{\circ} 5.786 / 06$ ).

Os conceitos de faculdades integradas e estabelecimentos isolados podem ser extraídos do art. 12 , do revogado Decreto $\mathrm{n}^{\mathrm{o}} 3.860 / 01^{6}$, posto que as primeiras são IES com propostas de currículo em duas ou mais áreas de conhecimento, organizadas mediante regimento comum e direção central. Os estabelecimentos ou faculdades isolados, por conseqüência, são IES com currículo ou currículos em apenas uma área de conhecimento, possuindo direção e regimento interno exclusivos.

Destaca-se que o art. 12, do Decreto $\mathrm{n}^{\circ}$ 5.773/06, parece não ter previsto a subdivisão entre faculdades integradas e estabelecimentos isolados, quando se pensa em credenciamento e recredenciamento de IES. Apesar da norma não prever expressamente, a diferenciação doutrinária deve permanecer, para respeitar a realidade social, política, econômica e regional das instituições, no momento de suas respectivas avaliações.

Apresentado o que se denomina heterogeneidade institucional, Cunha (2003) destaca a necessidade de discussão sobre a concepção de universidade, sem olvidar a pluralidade existente no Brasil. Trata-se de um alerta de extrema importância, já que o surgimento tardio das universidades brasileiras e a sua forma de constituição (associação por unidades de ensino), contribuirá à dissolução do citado conceito às condições reais de meras faculdades.

Por sua vez, o art. 45 LDB estabelece que a educação superior será fornecida em IES, “com variados graus de abrangência ou especialização". Nesse contexto, o art. 12 Decreto n

$\S 3^{\text {o }}$ As universidades somente serão criadas por credenciamento de instituições de ensino superior já credenciadas e em funcionamento regular, com qualidade comprovada em avaliações coordenadas pelo Ministério da Educação.

${ }^{6}$ Art. 12 Decreto $\mathrm{n}^{\mathrm{o}}$ 3.860/01 (revogado) - Faculdades integradas são instituições com propostas curriculares em mais de uma área de conhecimento, organizadas para atuar com regimento comum e comando unificado.

Revista da Faculdade Mineira de Direito, v.12, n. 23, jan./jun. 2011 - ISSN 1808-9429. 
5.773/06 explicita que as IES, em função da organização e prerrogativas acadêmicas, são credenciadas como faculdades, centros universitários e universidades ${ }^{7}$.

Os diversos níveis de abrangência ou especialização, mencionados nos arts. 45 LDB, 12 e 13 Decreto $\mathrm{n}^{\mathrm{o}}$ 5.773/06, são outorgados pelos atos autorizativos. Envolvem a classificação das IES, segundo a natureza institucional ou administrativa e parecem formulados, segundo Ranieri (2000), em função da vinculação entre ensino e pesquisa, ou seja, sua associação ou não. Assim, o art. 52 LDB utiliza tal parâmetro para conceituar as universidades, apresentando o maior grau de abrangência e especialização do sistema educacional brasileiro, em conformidade com o art. 207, caput, CR/88.

Nesse ínterim, os arts. 13, Decreto $n^{\circ} 5.773 / 06$, e $2^{\circ}$, § $3^{\circ}$, Decreto $n^{\circ} 5.786 / 06$ fixam que as IES somente poderão ser credenciadas, pela primeira vez, como faculdades. Ademais, as universidades ou centros universitários terão credenciamento especial, convertendo o credenciamento ordinário das faculdades em funcionamento, desde que possuam padrão de qualidade satisfatório, ante uma avaliação positiva no Sistema Nacional de Avaliação da Educação Superior (SINAES). Ranieri (2000), comentando os atos administrativos normativos da época, já apresentava críticas sobre regulamentação quase idêntica à atual, posto que é impossível criar, de início, centros universitários (seria apenas um credenciamento como tal), o que não está expressamente previsto no art. 16, inciso II, LDB. Portanto, "há aqui uma limitação de direitos, tanto para a iniciativa privada quanto para o próprio poder público federal, incompatível com a ordem constitucional" (RANIERI, 2000, p. 211).

Este artigo é preponderantemente teórico-documental, exaurindo a parte legal que trata do tema abordado, sob uma perspectiva dogmática, empregada como forma de análise dos resultados.

\section{REGULAÇÃO DOS ATOS AUTORIZATIVOS}

Dito isso, no sistema federal de ensino, os procedimentos referentes à avaliação e constatação das condições de funcionamento das IES e de seus cursos, bem como a definição de indicadores de qualidade e desempenho, e dos requisitos processuais a serem cumpridos,

\footnotetext{
${ }^{7}$ A origem da classificação quanto à natureza institucional ou administrativa remonta a Lei $\mathrm{n}^{\mathrm{o}} 5.540$, de 28 de novembro de 1968, que, em seu art. $8^{\circ}$, dispõe: “os estabelecimentos isolados de ensino superior deverão, sempre que possível incorporar-se a universidades ou congregar-se com estabelecimentos isolados da mesma localidade ou de localidades próximas, constituindo, neste último caso, federações de escolas, regidas por uma administração superior e com regimento unificado que lhes permita adotar critérios comuns de organização e funcionamento" (Revogado pela Lei n 9.394/96).
} 
estão presentes nas Leis $\mathrm{n}^{\circ}$ 10.861, de 14 de abril de 2004, e 10.870, de 19 de maio de 2004; nos Decretos $n^{\circ}$ 5.773/06 e 5.786/06; nas Portarias Normativas $n^{\circ}$ 01, de 10 de janeiro de 2007, e 40, de 12 de dezembro de 2007; nas Portarias MEC n ${ }^{\circ}$ 300, de 30 de janeiro de 2006, 563, de 21 de fevereiro de 2006, e 1.027, de 15 de maio de 2006; e nas Portarias $\mathrm{n}^{\circ} 2.051$, de 09 de julho de 2004, 107, de 22 de julho de 2004, e 147, de 02 de fevereiro de 2007.

Nesse contexto, o Decreto $\mathrm{n}^{\circ}$ 5.773/06 formula a regulação das IES e dos cursos de graduação e seqüenciais, estabelecendo os atos autorizativos, a partir do seu art. $9^{\circ}$. Tal artigo mostra-se prescindível, já que repete integralmente o art. 209, incisos I e II, CR/88, apresentando a liberdade do segmento particular em atuar na educação superior, desde que cumpra com as normas gerais da educação brasileira e inicie suas atividades mediante autorização e avaliação pelo Poder Público (art. $9^{\circ}$ Decreto no $^{\circ}$ 5.773/06).

Com isso, o art. 10, caput e $\S \S$, Decreto $\mathrm{n}^{\circ} 5.773 / 06$, determina que o ato autorizativo do Poder Público é indispensável ao funcionamento de IES e ao oferecimento de curso de nível superior.

Ademais de estabelecerem os limites da atuação dos agentes públicos e particulares na educação superior e de serem temporalmente limitados ${ }^{8}$, os atos administrativos autorizativos possuem as seguintes modalidades, a serem analisadas nas próximas partes deste estudo: autorização, reconhecimento e renovação de reconhecimento de cursos superiores; credenciamento e recredenciamento de instituições; além de suas eventuais e respectivas alterações. Dessa forma, qualquer alteração nos elementos ${ }^{9}$ que ensejaram o ato autorizativo originário determina a sua modificação, processando-se como pedido de aditamento. Assim, o ato autorizativo detém prevalência sobre qualquer documento constante no processo administrativo. Salienta-se que os pedidos de ato autorizativo serão analisados utilizando-se o relatório de avaliação e os documentos comprobatórios, juntados pelas entidades interessadas no feito administrativo ou, ainda, as provas pleiteadas pela Secretaria competente, no exercício de sua atividade instrutória.

No que se refere às limitações temporárias do ato autorizativo, qualquer prazo constante no decreto terá seu dia de inicio, na data da publicação do ato administrativo, que terá validez até o próximo ciclo avaliativo. Contudo, o referido prazo não será aplicável aos atos autorizativos, também com período determinado, expedidos antes da vigência do Decreto

\footnotetext{
${ }^{8}$ Os atos autorizativos terão prazos limitados e serão renovados, periodicamente, após processo regular de avaliação, de acordo com a Lei $n^{\circ} 10.861 / 04$ e com o $\S 3^{\circ}$, do art. 10 Decreto $n^{\circ}$ 5.773/06.

${ }^{9} \mathrm{O}$ art. $10, \S 4^{\circ}$, Decreto $\mathrm{n}^{\circ} 5.773 / 06$ fornece casos de modificação dos elementos constitutivos do ato autorizativo, como por exemplo, a "forma de atuação dos agentes da educação superior após a expedição do
} 
$\mathrm{n}^{\circ} 5.773 / 06$, conforme seu art. 70. Todavia, haverá prorrogação do prazo do ato autorizativo por, no máximo, 01 ano, quando a IES apresentar pedido de recredenciamento, reconhecimento ou renovação de reconhecimento de seu curso de ensino superior, desde que o requerimento seja devidamente protocolizado. Caso haja a publicação de ato autorizativo inicial para curso superior, o requerente deve providenciar o início do funcionamento das atividades educacionais, isto é, a efetiva oferta de aulas, em 12 meses, sob pena de caducidade (art. 68, caput e $\S 2^{\circ}$, Decreto $\mathrm{n}^{\mathrm{o}} 5.773 / 06$ ).

Nas hipóteses de caducidade do ato autorizativo ou de decisão final ${ }^{10}$, contrária ao pedido em procedimento credenciamento de IES, inclusive de unidade fora da sede, e de autorização de curso superior, o requerente ou os interessados somente poderão manejar novo requerimento idêntico passados 02 anos, da data do encerramento do processo administrativo $\left(\S 1^{\circ}\right.$, do art. 68 Decreto $\left.^{\circ} 5.773 / 06\right)$.

Por fim, prevê-se, ainda, a possibilidade de se ofertar curso de ensino superior ou de a IES funcionar sem ato autorizativo, o que, em ambos os casos, implicaria irregularidade administrativa, acarretando sanções de índole cível ou penal. As mesmas conseqüências incidem quando faltar qualquer ato autorizativo, dos ora explicitados, ao funcionamento da instituição, proibindo-se a admissão de novos discentes pelas IES. Não por demais, os procedimentos de autorização ou credenciamento em trâmite serão suspensos por 02 anos, se a instituição não universitária ofertar curso antes da necessária autorização inicial. Como conseqüência da situação irregular, o MEC pode determinar, em decisão fundamentada e com índole de medida cautelar administrativa, a suspensão preventiva da admissão de alunos novos em IES ou em cursos irregulares, impedindo a ocorrência de prejuízos a tais discentes. Da referida medida caberá recurso administrativo ao Conselho Nacional de Educação (CNE), no prazo de 30 dias da ciência da decisão, que não será dotado de efeito suspensivo ${ }^{11}$ (art. 11 Decreto $\left.n^{\circ} 5.773 / 06\right)$.

\footnotetext{
ato autorizativo, relativa à mantenedora, à abrangência geográfica das atividades, habilitações, vagas, endereço de oferta dos cursos ou qualquer outro elemento relevante para o exercício das funções educacionais".

${ }^{10}$ Entenda-se não mais passível de recurso administrativo ou após processo judicial, com decisão transitada em julgado, isto é, não sujeita a recurso judicial.

11 Efeito suspensivo é uma expressão derivada do direito processual, segundo a qual a decisão de conteúdo positivo não produzirá efeitos no mundo jurídico até o julgamento do recurso próprio, contra ela interposto. Decisão com conteúdo positivo é aquela que defere requerimento ou julga procedente pedido, na hipótese o da Secretaria do MEC, competente para atuar no caso concreto. Nesse sentido, "há decisões que somente produzem efeitos depois de escoado o prazo recursal para sua impugnação - como, por exemplo, a sentença. Nestes casos, afirma-se que o recurso é recebido no efeito suspensivo, embora este não suspenda propriamente os efeitos da decisão recorrida (uma vez que ainda não foram gerados), mas evita que a decisão produza efeitos até o julgamento do recurso". [...] "Na realidade, quando se afirma que determinado recurso possui efeito suspensivo, não se permite que a decisão que por ele possa ser recorrida produza efeitos após sua publicação. Uma decisão impugnável por recurso que possui efeito suspensivo somente pode produzir efeitos
} 


\title{
3. AUTORIZAÇÃO E RECONHECIMENTO DE CURSOS SUPERIORES
}

A LDB foi rigorosa em matéria de autorização e reconhecimento de cursos. Nos termos do art. 46 e $\S \S, \mathrm{LDB}$, os prazos de ambos os institutos são limitados e dependem de prévia avaliação para renovação que, dependendo do resultado, pode ensejar a desativação de cursos ou habilitações, a eventual intervenção na IES, a suspensão de prerrogativas da autonomia $^{12}$ ou o descredenciamento. Quando se tratar de IES pública, o Poder Executivo, responsável pela manutenção da mesma, deverá acompanhar o processo de saneamento, fornecendo subsídios financeiros adicionais para a superação das deficiências apontadas, se necessários.

Assim, no sistema federal de ensino, os procedimentos de autorização e reconhecimento de cursos de graduação, bem como suas habilitações, estão disciplinados nas Leis $\mathrm{n}^{\mathrm{o}} 10.861 / 04,10.870 / 04$, nos Decretos $\mathrm{n}^{\mathrm{o}} 5.773 / 06,5.786 / 06$ e em outros atos administrativos normativos indicados anteriormente ${ }^{13}$. Essas leis e decretos sujeitam a abertura de cursos de direito, medicina, odontologia e psicologia à respectiva manifestação do Conselho Federal da Ordem dos Advogados do Brasil ou do Conselho Nacional de Saúde ${ }^{14}$, antes mesmo da autorização do MEC, inclusive em universidades e centros universitários, em conformidade com o art. $28, \S 2^{\circ}$, Decreto $n^{\circ} 5.773 / 06$, parágrafo com redação dada pelo Decreto $n^{\circ} 5.840$, de 13 de julho de 2006. Com isso e ainda na vigência da regulamentação antiga:

\begin{abstract}
A autorização e o reconhecimento de cursos de ensino superior são atos administrativos unilaterais, vinculados, de competência do ministro da Educação ou do secretario de Estado da Educação (dependendo do sistema de ensino em que é oferecido), exarados após deliberação do Conselho Nacional de Educação no caso do sistema federal (artigo $9^{\circ}, \S 2^{\circ}$, "d", da Lei n ${ }^{\circ} 4.024 / 61$, com a redação dada pela Lei $\mathrm{n}^{\mathrm{o}}$ 9.131/95), ou do Conselho Estadual de Educação, que garantem, respectivamente, a possibilidade de funcionamento inicial do curso e a expedição de diplomas válidos em todo o território nacional (cf. artigo 48, da LDB). Ambos conferem "qualificações" por prazo determinado, com a finalidade de garantir
\end{abstract}

após escoado o prazo recursal, ou a partir do momento em que a parte aceitar a decisão ou renunciar ao direito de recorrer" (MARINONI; ARENHART, 2007, p. 516).

12 Ranieri (2000) pensa que a suspensão temporária da autonomia somente se aplica as IES não universitárias, tendo em vista o comando constitucional contido no art. $207 \mathrm{CR} / 88$. Ademais, quando for pública a IES a ser sancionada, alega que a sanção provisória somente poderá ser imposta por lei, ante o cumprimento do princípio do paralelismo das formas.

13 Para analisar os antigos procedimentos de autorização, reconhecimento e renovação do reconhecimento de cursos superiores, ver BRASIL; MEC; INEP, 2007, p. 52-55 e 58-73.

${ }^{14}$ Ainda de acordo com Ranieri (2000), existe uma relação entre tais disposições e o art. 45 LDB, que aumentou a função fiscalizadora de algumas organizações profissionais, ante a natureza acadêmica dos diplomas de graduação. Destacou, ainda, que "os serviços de fiscalização de profissões regulamentadas são exercidas em caráter privativo, por delegação do poder público, mediante autorização legislativa (Lei nº 9.649, de 27/5/98, artigo 58)" (RANIERI, 2000, p. 175, nota 37).

Revista da Faculdade Mineira de Direito, v.12, n. 23, jan./jun. 2011 - ISSN 1808-9429. 
padrão de qualidade ao ensino, conforme exige o artigo 206, VII, da Constituição Federal. (RANIERI, 2000, p. 175).

De acordo com Ranieri (2000), são, ademais de atos administrativos unilaterais, vinculados ${ }^{15}$, posto que se forem cumpridas todas as condições legais, em processo regular de avaliação (art. 46, caput, LDB), o Executivo é obrigado a autorizar ou reconhecer os cursos superiores. Destaca-se que nos procedimentos de autorização e reconhecimento devem-se respeitar os princípios constitucionais do contraditório e da ampla defesa (art. $5^{\circ}$, inciso LV, $\mathrm{CR} / 88$ ), sem prejuízo do da inafastabilidade do controle jurisdicional (art. $5^{\circ}$, inciso XXXV, $\mathrm{CR} / 88$ ), por serem direitos fundamentais garantidos a todos no Brasil, sejam pessoas físicas ou jurídicas, de direito público ou privado. Por tais motivos, o Ministro da Educação só pode homologar os pareceres sobre as solicitações de autorização e reconhecimento, após análise de eventual recurso administrativo, interposto ao órgão competente, para seu conhecimento ${ }^{16}$. Ranieri (2000) explicita, ademais, que a natureza dos atos nos referidos procedimentos são diferentes, já que a autorização classifica-se como constitutiva na medida em "que atribui à pessoa jurídica uma qualidade que até então não possuía, ainda que apresentasse os requisitos necessários para recebê-la" (RANIERI, 2000, p. 176), produzindo efeitos a partir do momento em que é expedida. Por outro lado, o reconhecimento classifica-se como ato declaratório, "posto exprimir a declaração de algo já existente" (RANIERI, 2000, p. 176), ensejando efeitos retroativos à data da autorização. Passados os prazos de autorização e reconhecimento de cursos, terminam as qualificações que concedem o direito às IES em abrir vagas em processo seletivo de discentes e emitir diplomas, respectivamente. Na hipótese de não renovação, sempre precedida de processo administrativo (art. $5^{\circ}$, inciso LIV, CR/88), que respeite o crivo do contraditório e da ampla defesa (art. $5^{\circ}$, inciso LV, CR/88), sanciona-se a IES.

\footnotetext{
15 “O chamado 'poder vinculado', na realidade, não encerra 'prerrogativa` do Poder Público, mas, ao contrário, dá idéia de restrição, pois, quando se diz que determinada atribuição da Administração é vinculada, quer-se significar que está sujeita à lei em praticamente todos os aspectos. O legislador, nessa hipótese, preestabelece todos os requisitos do ato, de tal forma que, estando eles presentes, não cabe à autoridade administrativa senão editá-lo, sem apreciação de aspectos concernentes à oportunidade, conveniência, interesse público, eqüidade. Esses aspectos foram previamente valorados pelo legislador" (DI PIETRO, 2004, p. 86).

${ }^{16}$ Nesse sentido, a seguinte decisão: "CONSTITUCIONAL. MANDADO DE SEGURANÇA. PRINCIPIO DO CONTRADITÓRIO APLICÁVEL AO PROCESSO ADMINISTRATIVO. CONCESSÃO DA SEGURANÇA. A Lei nº 9.131, de 1995, ao enumerar as atribuições da Câmara de Educação Superior, instituiu o recurso contra seus pareceres a ser julgado pelo Conselho Pleno. O pedido de reconhecimento de curso de graduação, em face da legislação de regência, não pode ser homologado pelo Ministério da Educação, antes que o Conselho Pleno aprecie o recurso interposto, in opportuno tempore, pelo interessado. No sistema jurídico-constitucional vigente, a instituição de decisão irrecorrível, ainda que na esfera administrativa, é inconciliável com o principio constitucional da ampla defesa que, por si, pressupõe mais de um grau de jurisdição. Segurança concedida. Decisão unânime" (BRASIL; STJ; $1^{\text {a }}$ Seção; Mandado de Segurança n ${ }^{\circ}$ 4831/DF; Rel. Min. Demócrito Reinaldo; votação unânime; julgamento em 23 de abril de 1997; publicação no DJU de 16 de junho de 1997, p. 27308; RSTJ 97/38).
}

Revista da Faculdade Mineira de Direito, v.12, n. 23, jan./jun. 2011 - ISSN 1808-9429. 
No sistema federal de ensino, tanto as autorizações de funcionamento de cursos superiores, quanto os seus reconhecimentos, serão efetivados por ato homologatório do Poder Executivo, por meio de seu Ministro da Educação, prévio parecer do órgão pertinente, em conformidade com o art. $2^{\circ}$ e seu parágrafo único, Lei $\mathrm{n}^{\circ}$ 9.131/95, parágrafo introduzido pelo art. 46 Lei n ${ }^{\circ} 9.649 / 98$.

Os institutos em questão e as disposições infraconstitucionais supramencionadas possuem respaldo constitucional nos arts. 206, inciso VII, e 209, inciso II, CR/88 ${ }^{17}$ (princípio da garantia do padrão de qualidade), o que, por si, parece justificar e amparar a existência do sistema nacional de avaliação atual.

Dito isso, o Decreto $\mathrm{n}^{\mathrm{o}}$ 5.773/06 apresenta a regulação dos atos autorizativos, paras as IES e seus cursos de graduação ou seqüenciais, no âmbito do sistema federal de ensino.

Portanto, o art. 27, caput e $\S \S$, Decreto $n^{\circ} 5.773 / 06$ determina, com precisão, que os cursos superiores, de graduação ou seqüenciais, em faculdades ou instituição só poderão funcionar com prévia autorização do MEC. Destaca-se que os cursos e programas, ofertados por instituições de pesquisa científica e tecnológica, sujeitam-se a regras específicas do ato administrativo normativo em tela.

Pelo contrário, salientam-se as especificidades inerentes às universidades e aos centros universitários, nos limites de sua autonomia e privilégios assemelhados, que não necessitam de autorização para ofertar curso superior. Contudo, devem informar à Secretaria competente a abertura dos mesmos, para viabilizar a supervisão, avaliação e futuro reconhecimento, no prazo máximo de 60 dias do início das atividades. Isso também se aplica à criação de novas turmas, cursos congêneres e alterações que acarretem acréscimo no número de alunos das IES, bem como nas alterações das condições e elementos, existentes no ato de credenciamento, em conformidade com o já apresentado art. 28 Decreto nº 5.773/06. Repitase que tal artigo condiciona a criação de cursos de direito, medicina, psicologia e odontologia ao pronunciamento dos conselhos pertinentes, inclusive em universidades e centros universitários, antes da autorização do MEC para as faculdades.

As fases do procedimento administrativo de autorização estão indicadas nos arts. 29 e 31, Decreto $\mathrm{n}^{\mathrm{o}} 5.773 / 06$, iniciando-se com o protocolo do pedido na Secretaria do MEC competente, segundo as atribuições indicadas nos $\S \S$, do art. $5^{\circ}$ do mesmo decreto, juntando a documentação indispensável à instrução do processo (art. 30 Decreto no 5.773/06). Poderá ser

\footnotetext{
${ }^{17}$ Em sentido equivalente Ranieri (2000), que acrescenta que tais artigos da CR/88 "apontam para concepção da educação superior como produto e do ensino como 'serviço público' concedido à iniciativa privada" (RANIERI, 2000, p. 177).
} 
ordenada a apresentação de novos documentos, baixando-se o feito em diligência. Após e em função do impulso oficial ${ }^{18}$, a mesma Secretaria procederá a análise dos documentos apresentados, o que equivale a um juízo de admissibilidade do processo administrativo, verificando se estão presentes todas as condições e pressupostos processuais, como requisitos necessários ao desenvolvimento regular do processo ${ }^{19}$. Depois, será determinada a avaliação no local, remetendo os autos ao Instituto Nacional de Estudos e Pesquisas Educacionais Anísio Teixeira (INEP), para designação de uma comissão de especialistas para o intento. Apresentados os relatórios e pareceres avaliativos pela mencionada comissão, os autos do processo são remetidos à Secretaria competente, para decisão final sobre o mérito do pedido de autorização, analisando-se a própria pretensão da IES, o seu âmbito e a sua extensão, no que toca ao curso superior submetido ao procedimento. Assim, o Secretário, com atribuição para decidir o caso, observando as normas gerais educacionais, poderá deferir o pedido de autorização, sem ressalvas, ou deferir o requerimento, em caráter experimental (art. 81 LDB), ou, ainda, indeferir, fundamentadamente, a autorização do curso superior (art. 32 Decreto $\mathrm{n}^{\mathrm{o}}$ 5.773/06). Nos dois últimos casos, em virtude do prejuízo causado, a decisão do Secretário poderá ser impugnada por recurso administrativo ao CNE, no prazo de 30 dias (art. 33 Decreto $\left.\mathrm{n}^{\circ} 5.773 / 06\right)$.

Por sua vez, o reconhecimento de curso, como requisito indispensável para a validade nacional do seu diploma, devidamente registrado (art. 34 Decreto $\mathrm{n}^{\circ} 5.773 / 06$ ) ${ }^{20}$, terá as seguintes fases procedimentais: a IES iniciará o procedimento, mediante protocolo do pedido, no período compreendido entre a metade do prazo previsto para a integralização da carga horária do curso e $75 \%$ desse mesmo prazo. O pedido de reconhecimento será instruído com o comprovante de recolhimento da taxa de avaliação in loco, de acordo com os critérios do art. $3^{\circ}$, da Lei n ${ }^{\circ}$ 10.870/04; com o Projeto Pedagógico de Curso (PPC), munido de dados sobre o número de alunos, turnos e demais elementos acadêmicos pertinentes; relação de docentes,

\footnotetext{
${ }^{18}$ Trata-se de expressão de direito processual, que determina o prosseguimento do feito até decisão final, uma vez apresentado o pedido inicial do interessado, independentemente de novos requerimentos incidentais nesse sentido. Da mesma forma, [...] "embora a iniciativa da abertura do processo seja da parte, o seu impulso é oficial, isto é, do juiz (art. 262), que promove o andamento do feito até o provimento final, independentemente de provocação dos interessados" (THEODORO JÚNIOR, 2007, p. 30). A referência na citação diz respeito ao art. 262 Código de Processo Civil (CPC): "o processo civil começa por iniciativa da parte, mas se desenvolve por impulso oficial".

${ }^{19}$ Ressaltam-se as especificidades inerentes aos cursos de graduação à distância, de direito e relativos à saúde, constantes nos $\S 2^{\circ}$ : "a Secretaria solicitará parecer da Secretaria de Educação a Distância, quando for o caso" e $\S 3^{\circ}$ "a Secretaria oficiará o Conselho Federal da Ordem dos Advogados do Brasil ou o Conselho Nacional de Saúde, nas hipóteses do art. 28”, do citado art. 31 Decreto n 5.773/06.

${ }^{20}$ Destaca-se que "o reconhecimento de curso na sede não se estende às unidades fora de sede, para registro do diploma ou qualquer outro fim", conforme o parágrafo único, do art. 34 Decreto no 5.773/06, incluído pelo Decreto $\mathrm{n}^{\circ}$ 6.303, de 12 de dezembro de 2007.
} 
devidamente incluídos no cadastro nacional; e, comprovante de disponibilidade do imóvel para as atividades de ensino. Quando se tratar de cursos já autorizados, na vigência do decreto em questão, dispensa-se a IES da apresentação do PPC, com suas informações, e do comprovante de disponibilidade do imóvel, fazendo constar apenas os elementos de atualização dos documentos, anexados no momento da autorização. No que tange à Secretaria competente, a mesma terá em conta, ao emitir os atos autorizativos ${ }^{21}$, os relatórios elaborados na última avaliação do SINAES, podendo solicitar ao INEP a realização de nova avaliação in loco, caso haja alguma irregularidade na levada a cabo (art. 35, caput e seus $\S \S$, Decreto $\mathrm{n}^{\circ}$ 5.773/06). Nessa hipótese, não é possível cobrar nova taxa de avaliação, posto que o parágrafo único, do art. $1^{\circ}$ Lei $\mathrm{n}^{\mathrm{o}} 10.870 / 04$, só admite tal exigência quando ficarem configurados todos os elementos ensejadores do $\S 1^{\circ}$, do art. $46 \mathrm{LDB}$, isto é, avaliação prévia com resultado insatisfatório e transcurso do prazo outorgado para saneamento das deficiências encontradas na citada avaliação.

Em conformidade com os arts. 38 e 39, Decreto $n^{\circ}$ 5.773/06, a decisão de deferimento do reconhecimento de curso superior se respaldará nos elementos colhidos nos processos avaliativos do SINAES. Não obstante, quando o resultado da avaliação, realizada pelo SINAES, for insatisfatório, deverá ser celebrado protocolo de compromisso, nos termos do art. 10, Lei $\mathrm{n}^{\mathrm{o}} 10.861 / 04$ e dos arts. 60 e 61, Decreto $\mathrm{n}^{\circ}$ 5.773/06. Uma vez firmado o protocolo de compromisso e expirado o seu prazo, sem o adequado cumprimento das metas nele formuladas, será instaurado processo administrativo para a cassação da autorização de funcionamento, segundo procedimento dos arts. 10, $\S 2^{\circ}$, inciso II, $\S 3^{\circ}$, Lei $n^{\circ} 10.861 / 04$; e, 63, inciso II, Decreto $n^{\circ} 5.773 / 06$. A decisão que instaurar o citado processo será passível de recurso administrativo ao CNE, no prazo de 30 dias (art. 40 Decreto $n^{\circ} 5.773 / 06$ ).

Com relação ao procedimento de renovação do reconhecimento de curso superior, o mesmo se inicia mediante solicitação expressa da IES, ao final de cada ciclo avaliativo do

\footnotetext{
${ }^{21}$ Antes da expedição do ato, a exemplo do procedimento de autorização, "o reconhecimento de cursos de graduação em direito e em medicina, odontologia e psicologia, deverá ser submetido, respectivamente, à manifestação do Conselho Federal da Ordem dos Advogados do Brasil ou do Conselho Nacional de Saúde", cujo "prazo para manifestação prevista no caput é de sessenta dias, prorrogável por igual período". Ademais, "nos processos de reconhecimento dos cursos de licenciatura e normal superior, o Conselho Técnico Científico da Educação Básica, da Fundação Coordenação de Aperfeiçoamento de Pessoal de Nível Superior - CAPES, poderá se manifestar, aplicando-se, no que couber, as disposições procedimentais que regem a manifestação dos conselhos de regulamentação profissional" (art. 36, caput e seus $\S$, Decreto $n^{\circ} 5.773 / 06$, com redação dada pelo Decreto ${ }^{\circ}$ 6.303/07).

Portanto, sendo caso de curso com profissão regulamentada, a Secretaria deverá abrir prazo para que o órgão nacional de regulamentação profissional ofereça, caso queira, subsídios à decisão do MEC, em 60 dias. Decorrido tal prazo e havendo manifestação do referido órgão, a Secretaria abrirá novo prazo de 30 dias ao requerente, para manifestação. Após a instrução do feito, a Secretaria analisará os documentos e decidirá o pedido (art. 37, §§, Decreto $\mathrm{n}^{\circ}$ 5.773/06).
} 
SINAES $^{22}$, no prazo de 60 dias do término do mencionado período. Seu procedimento é idêntico ao do primeiro reconhecimento, tendo em vista o art. 41, Decreto $\mathrm{n}^{\mathrm{o}}$ 5.773/06. Ademais, havendo, na IES, mais de um curso de graduação a ser renovado, inclusive quando um deles for de tecnologia, a renovação de todos deverá ser procedida conjuntamente e ao mesmo tempo.

Existem especialidades para a autorização, o reconhecimento e a renovação de reconhecimento de cursos superiores de tecnologia, como dispõem os arts. 42 e 43, Decreto n ${ }^{\circ}$ 5.773/06, posto que serão amparados no catálogo de denominações publicado pela Secretaria de Educação Profissional e Tecnológica (SETEC). A inserção do curso no mencionado catálogo, com tal perfil profissional, também será realizado pela SETEC, mediante solicitação da IES ou sem qualquer provocação, ou seja, de ofício ${ }^{23}$. A SETEC ainda poderá, motivadamente, sugerir ao CNE a exclusão da denominação de curso tecnológico do catálogo. O requerimento da instituição será acompanhado de elementos que comprovem a consistência da área técnica definida, em função das diretrizes curriculares nacionais.

Nos processos de autorização, reconhecimento ou renovação de reconhecimento de cursos superiores de tecnologia, o Secretario da SETEC poderá, cumprindo as normas gerais educacionais, deferir o pedido, tendo em vista o catálogo de denominações de cursos, publicado pela mesma Secretaria; aceitar a solicitação, determinando a inclusão da denominação do curso no catálogo; prover o requerimento, outorgando caráter experimental do curso (art. $81 \mathrm{LDB}$ ); deferir o pleito, somente para registrar os diplomas, vedando a admissão de novos discentes; ou ainda, indeferir o pedido, fundamentadamente. Além disso, as regras inerentes à autorização, ao reconhecimento e à renovação de reconhecimento de cursos superiores aplicam-se, subsidiariamente, aos procedimentos de mesma índole, mas referentes aos cursos de tecnologia (art. 44 Decreto $n^{\circ}$ 5.773/06).

Por último, os feitos de autorização, reconhecimento e renovação de reconhecimento de cursos superiores que estejam em trâmite perante o CNE e que já tenham sido distribuídos a Conselheiros relatores, lá terão seu curso normal, respeitando-se o novo procedimento do

\footnotetext{
${ }^{22}$ Segundo o art. $4^{\circ}$ Lei $\mathrm{n}^{\circ} 10.870 / 04$ - O credenciamento ou a renovação de credenciamento das instituições de educação superior e o reconhecimento ou a renovação de reconhecimento de cursos de graduação terão prazo de validade de até 5 (cinco) anos, exceção feita às universidades, para as quais esse prazo será de até 10 (dez) anos.

Parágrafo único. Os prazos de que trata este artigo serão fixados mediante critérios estabelecidos pelo Ministério da Educação e de acordo com os resultados da avaliação, podendo ser por ele prorrogados.

$\mathrm{O} \S 4^{\circ}$, do art. 13, e os incisos I e II, do art. 59 Decreto $\mathrm{n}^{\circ}$ 5.773/06, dão aplicabilidade ao citado parágrafo único, com relação ao credenciamento de IES, pois "o primeiro credenciamento terá prazo máximo de três anos, para faculdades e centros universitários, e de cinco anos, para universidades".

${ }^{23}$ Entenda-se "por dever inerente ao cargo, ou ofício; em função da autoridade própria. O mesmo que ex officio" (NUNES, 1993, p. 306).
}

Revista da Faculdade Mineira de Direito, v.12, n. 23, jan./jun. 2011 - ISSN 1808-9429. 
ato administrativo normativo em questão. Contrariamente, caso os processos não tenham sido distribuídos aos relatores do CNE, serão remetidos à Secretaria competente do MEC, para começo do procedimento, como foi mencionado (art. 74 Decreto ${ }^{\circ} 5.773 / 06$ ).

\section{CREDENCIAMENTO DE INSTITUIÇÕES}

Os atos de credenciamento e recredenciamento manifestam, expressa e formalmente, os diversos níveis de abrangência. Terão duração limitada, mas poderão ser renovados, através de prévio processo administrativo de avaliação, em conformidade com o art. 46 LDB e com o $\S 3^{\circ}$, do art. 10, Decreto $n^{\circ} 5.773 / 06$.

É sabido que a educação superior, a exemplo dos demais níveis de ensino, é livre a iniciativa privada, desde que sejam respeitadas as normas gerais educacionais e que haja autorização e avaliações qualitativas por parte do Poder Público, nos termos dos arts. 209, incisos I e II, CR/88 e $9^{\circ}$, Decreto $n^{\circ}$ 5.773/06. Dessa forma, o funcionamento de IES e o oferecimento de curso superior são medidas dependentes de ato administrativo autorizativo da Administração Pública (art. 10, caput, Decreto $n^{\circ}$ 5.773/06). Com isso, o credenciamento e o recredenciamento de IES são modalidades de atos administrativos autorizativos, segundo o $\S$ $1^{\circ}$, art. 10 Decreto ${ }^{\circ} 5.773 / 06$. Nesse sentido:

\footnotetext{
Credenciamento e recredenciamento constituem atos administrativos unilaterais, vinculados, de natureza constitutiva e de competência do ministro da Educação ou do secretário de Estado da Educação (conforme a inserção da instituição nos diversos sistemas de ensino), que atestam, periodicamente, a qualificação acadêmica mínima para o funcionamento das instituições de ensino; bem como o atendimento, pelas pessoas jurídicas de direito privado, mantenedoras de instituições de ensino superior, sem finalidade lucrativa, das condições e requisitos elencados no artigo $2^{\circ}$, do Decreto no 2.306/97 (cf. § único, do artigo $2^{\circ}$ ) (RANIERI, 2000, p. 214).
}

Apesar de o conceito apresentado fazer referência ao art. $2^{\circ}$, parágrafo único, Decreto n 2.306/97, já revogado, o mesmo é equivalente ao atual art. $7^{\circ}-\mathrm{B}$, parágrafo único, Lei $\mathrm{n}^{\circ}$ 9.131/95, com redação dada pela Lei $n^{\circ}$ 9.870/99. De qualquer forma, tal conceito mostra todos os elementos identificadores da definição de credenciamento e recredenciamento.

Portanto, em função da expedição do Decreto $n^{\circ}$ 5.773/06, que regulamentou seus procedimentos administrativos e respectivas atribuições do Ministro da Educação, do CNE, da Secretaria de Educação Superior (SESu) e do INEP, nessas avaliações, o referido ato administrativo normativo, em conjunto com outros, devem ser analisados para que se tenha a indispensável noção sobre credenciamento e recredenciamento de IES. 
Na lição de Ranieri (2000), o Poder Público exerce sua função avaliadora no sistema federal de ensino, para efeitos de credenciamento e de sua renovação, basicamente mediante a análise do desempenho individual das IES, do ensino ofertado em cada curso de graduação, de seus programas de pós-graduação stricto sensu, da pesquisa realizada em seu interior e da produção acadêmica comprovada, cujos indicadores contêm pesos segundo a natureza de cada instituição.

Atualmente, os procedimentos de credenciamento e recredenciamento de IES estão previstos no Decreto $n^{\circ} 5.773 / 06$, da mesma forma que os de autorização, reconhecimento e renovação de reconhecimento de cursos superiores ${ }^{24}$.

Os arts. 12 e 13, Decreto $n^{\circ}$ 5.773/06, já estudados em parte anterior deste trabalho, indicam os níveis de especialização e abrangência nos quais as IES podem ser credenciadas e classificadas pela natureza institucional ou administrativa, ou seja, faculdades, centros universitários e universidades, as últimas com o maior grau de abrangência do sistema, em virtude do cumprimento integral do princípio da indissociabilidade do ensino, da pesquisa e da extensão. O início das atividades das IES está condicionado à expedição do ato de credenciamento pelo MEC. Como já dito e criticado, qualquer instituição só pode ser credenciada, originalmente, como faculdade, enquanto o credenciamento de universidades ou centros universitários é especial ${ }^{25}$, porque converte os anteriormente outorgados às faculdades em funcionamento normal e com qualidade reconhecidamente satisfatória. Na hipótese de indeferimento do pedido de credenciamento como universidade ou centro universitário, tal ato autorizativo pode ser concedido subsidiariamente como de centro universitário ou faculdade, respectivamente, quando cumpridos os requisitos específicos estatuídos na lei. O primeiro credenciamento terá prazo máximo de 03 anos, para faculdades e centros universitários, e de 05 anos, para universidades, como mencionado anteriormente.

Por sua vez, as fases procedimentais do credenciamento de IES são: protocolo do pedido na Secretaria competente, instruído com os documentos arrolados nos arts. 15 e 16, Decreto n 5.773/06; análise documental da admissibilidade pela mesma Secretaria; avaliação in loco pelo INEP; devolução dos autos para parecer meritório da Secretaria competente; remessa do feito ao CNE, para decisão; e, por fim, homologação da decisão do CNE, pelo Ministro de Estado da Educação (art. 14 Decreto no 5.773/06).

\footnotetext{
24 Para analisar os antigos procedimentos de credenciamento, recredenciamento de IES, autorização, reconhecimento e renovação de reconhecimento de cursos superiores, ver BRASIL; MEC; INEP, 2007, p. 5273.

${ }^{25}$ Em função da concessão dos privilégios da autonomia, previstos nos arts. $207 \mathrm{CR} / 88 ; 46, \S 1^{\circ}, 53$ e $54, \S \S$, LDB.
} 
Cabe fazer uma pausa para afirmar que alguns dos dispositivos supracitados só repetem os dispositivos legais, como, por exemplo, a alínea "g", do inciso I, do art. 15 Decreto $\mathrm{n}^{\mathrm{o}} 5.773 / 06$, que transcreve, com outras palavras, o art. $7^{\circ}-\mathrm{B}$, inciso $\mathrm{V}$, Lei $\mathrm{n}^{\mathrm{o}}$ 9.131/95. Não haveria necessidade de fazê-lo em função normativa ${ }^{26}$, mas o Presidente da República parece ter pretendido sistematizar e consolidar, em um único decreto regulamentar, todos os requisitos constantes no ordenamento constitucional e infraconstitucional.

Em conformidade com o art. 17, caput e $\S \S$, Decreto $\mathrm{n}^{\circ} 5.773 / 06$, o procedimento de credenciamento de IES começa com o recebimento do pedido e dos documentos, mediante protocolo, na SESu ou na SETEC, dependendo da instituição requerente. De ofício, a Secretaria pertinente analisará os documentos que instruíram o pedido, efetuando os juízos de admissibilidade e superficial de mérito. Procedida a análise documental em juízo de admissibilidade, a mesma Secretaria remeterá o feito ao INEP, para realização da avaliação no local. Nesse ínterim, a Secretaria poderá determinar as diligências essenciais à efetiva instrução do processo, objetivando subsidiar a deliberação final das autoridades competentes, isto é, Câmara de Educação Superior (CES) do CNE e o Ministro da Educação. Além disso, a Secretaria competente também deverá exarar parecer em cada feito após a sua instrução, segundo os arts. $5^{\circ}, \S \S 2^{\circ}, 3^{\circ}$ e $4^{\circ}$, inciso I, e $17, \S 4^{\circ}$, Decreto $n^{\circ} 5.773 / 06$, que se fundamentará, basicamente, no relatório de avaliação do INEP e no conjunto probatório, colhido no processo administrativo.

Após, o feito será enviado ao $\mathrm{CNE}$, para que sua CES delibere em ato único, devidamente fundamentado, sobre a conformidade do estatuto ou do regimento da IES, em face da legislação aplicável, a regularidade da instrução processual, realizada documentalmente e na avaliação in loco, e sobre o mérito do pedido. Se houver sucumbência do requerente, a decisão do CNE poderá ser impugnada por recurso administrativo, cujo pedido recursal será julgado pelo Conselho Pleno do mesmo CNE (art. 18 Decreto ${ }^{\circ}$ $5.773 / 06)$

Para concluir o procedimento, o CNE restitui o processo ao Ministro de Estado da Educação, para homologação da decisão da CES ou do Conselho Pleno, na hipótese de ter sido interposto o recurso regimental no CNE. O Ministro poderá, caso entenda necessário, em decisão motivada, devolver os autos ao CNE para reexame, segundo art. 19, caput e parágrafo único, Decreto no 5.773/06.

\footnotetext{
${ }^{26}$ Trata-se da competência responsável pela expedição de atos administrativos normativos, cujo conceito já foi apresentado.
}

Revista da Faculdade Mineira de Direito, v.12, n. 23, jan./jun. 2011 - ISSN 1808-9429. 
$\mathrm{O}$ art. 24 Decreto $\mathrm{n}^{\circ}$ 5.773/06, no credenciamento de campus fora da sede, determina que as universidades poderão pleiteá-lo, desde que seja no mesmo Estado membro, mas em Município distinto da abrangência geográfica do ato autorizativo vigente. Desse modo, o campus externo à sede fará parte do conjunto universitário, mas não se aproveitará das prerrogativas da autonomia. O pedido em tela será processado como aditamento do credenciamento originário, tramitando da mesma maneira. Com isso, veda-se o fornecimento de curso em unidade externa à sede da universidade, sem que haja o credenciamento anterior de tal campus e a autorização específica do citado curso, na forma procedimental prevista para o referido pedido.

Nota-se que o $\S 3^{\circ}$, do art. 24 Decreto $n^{\circ} 5.773 / 06$, incluído pelo Decreto n ${ }^{\circ}$ 6.303/07, aparenta violar os arts. $207 \mathrm{CR} / 88$ e 28 do próprio Decreto $\mathrm{n}^{\circ} 5.773 / 06$, posto que exigiu, além do credenciamento da nova unidade, fora da sede universitária, o deferimento de autorização específica do novo curso na referida localidade. Contudo, a limitação de tal direito é respaldada pelo art. 53, inciso I, LDB, que só permite a criação, organização e extinção de cursos superiores, sem autorização prévia do órgão competente, quando efetivada na sede da universidade. Ademais, o art. 207 CR/88 não outorga autonomia irrestrita para a criação de cursos, cabendo, então, à LDB tal previsão normativa. Para solucionar esta pequena antinomia no ato administrativo normativo em questão, o art. 28 Decreto ${ }^{\circ}$ 5.773/06 deveria ser modificado para: “Art. 28. As universidades e centros universitários, nos limites de sua autonomia, observado o disposto nos $\S \S 2^{\circ}$ e $3^{\circ}$ deste artigo, independem de autorização para funcionamento de curso superior, em sua sede, devendo informar à Secretaria competente os cursos abertos para fins de supervisão, avaliação e posterior reconhecimento, no prazo de sessenta dias."

No que se refere ao procedimento de recredenciamento, a IES deverá protocolizar tal pleito com os documentos pertinentes (art. 21 Decreto $n^{\circ} 5.773 / 06$ ), na Secretaria competente, ao final de cada ciclo avaliativo do SINAES, antes do seu término, aplicando-se as mesmas normas processuais acima indicadas, salvo disposição específica (art. 20 Decreto $n^{\circ}$ 5.773/06).

Conforme art. 22 Decreto $\mathrm{n}^{\circ}$ 5.773/06, para o deferimento da solicitação de recredenciamento da IES, indispensável à comprovação do funcionamento regular da mesma e do resultado do processo avaliativo do SINAES. Ademais, para fins de regulação, a Secretaria analisará o último relatório de avaliação do sistema, que esteja à disposição. Similarmente ao procedimento de reconhecimento de cursos, a Secretaria poderá determinar ao INEP que se proceda a nova avaliação no local, havendo motivos justificáveis para o intento. 
Na hipótese do resultado da avaliação de recredenciamento ser insuficiente, firmar-seá protocolo de compromisso, com base no art. 10 Lei no 10.861/04 e dos arts. 60 e 61, Decreto $n^{\circ} 5.773 / 06$, que, se for descumprido, ensejará a instauração de processo administrativo com o objetivo de se cassar a autorização de funcionamento da IES (arts. $10, \S 2^{\circ}$, inciso II, $\S 3^{\circ}$, Lei $\mathrm{n}^{\mathrm{o}}$ 10.861/04; e, 63, inciso II, Decreto $\mathrm{n}^{\mathrm{o}}$ 5.773/06), suspendendo-se o trâmite do pedido de recredenciamento, até decisão final e encerramento do referido processo (art. 23 Decreto $\mathrm{n}^{\circ}$ $5.773 / 06)$

Com relação às disposições finais, inerentes ao credenciamento de IES, seu processamento se dará juntamente com o requerimento de, no mínimo, um curso superior, levando em consideração os parâmetros administrativos de economicidade e racionalidade, segundo art. 67 Decreto $n^{\circ}$ 5.773/06. As unidades de IES, localizadas em Município distinto do da sede, quando instituídas e em funcionamento no dia da publicação do Decreto $\mathrm{n}^{\circ}$ 3.860/01, manterão seus privilégios inerentes à autonomia, pelo período previsto no ato autorizativo. Uma vez terminado o período, será necessária a submissão a novo processo de recredenciamento, simultâneo ao recredenciamento da universidade, momento em que será proferida decisão sobre as prerrogativas de autonomia de cada uma (art. 72 Decreto $\mathrm{n}^{\circ}$ 5.773/06). Ademais, o art. 75, do mesmo decreto, define que as avaliações de IES e cursos de graduação em funcionamento normal, com a intenção de recredenciamento, reconhecimento e renovação de reconhecimento, serão planejadas em portaria ministerial, utilizando-se a proposta da Comissão Nacional de Avaliação da Educação Superior (CONAES), prévio parecer da Secretaria competente e do INEP.

Assim, "o atendimento das condições mínimas de funcionamento gera para as instituições o direito ao credenciamento, ou ao recredenciamento, e, para o órgão público, o dever de emitir tais atos, sob pena de correição judicial” (RANIERI, 2000, p. 215).

Contrariamente, na hipótese de ser indeferido o credenciamento ou a sua renovação, ante as deficiências apontadas na avaliação, pode ocorrer a intervenção na IES, a suspensão provisória das prerrogativas da autonomia ou, até mesmo, o descredenciamento, conforme $\S$ $1^{\circ}$, art. 46 LDB. As medidas supracitadas são sanções às IES e, por tal motivo, exigem a existência prévia de processo administrativo, possibilitando à instituição interessada o exercício pleno do contraditório e da ampla defesa, na qualidade de direitos fundamentais (art. $5^{\circ}$, incisos LIV e LV, CR/88), "para que o processo de avaliação não se transforme em julgamento sem revisão, com penalização indesejada e arbitrária” (RANIERI, 2000, p. 215).

Em conclusão, cabe tratar da transferência de mantença entre mantenedoras diversas, como tema conexo à regulação dos procedimentos de credenciamento de IES, cuja previsão 
legal está no art. 25, $\S \S$, Decreto $n^{\circ}$ 5.773/06. Desse modo, as modificações na mantença de qualquer IES deverão ser apreciadas pelo MEC, obrigando que a nova mantenedora apresente a documentação necessária ao credenciamento primário, indicada no art. 15 , inciso I, do mesmo ato normativo, sem prejuízo do instrumento jurídico ${ }^{27}$ que deu ensejo à transferência da mantença. Tramitará como pedido de aditamento ao ato autorizativo vigente, possuindo distribuição e decisão específicas das autoridades com atribuições para sua análise. Por outro lado e em qualquer situação, proíbe-se a transferência de cursos ou programas entre mantenedoras, bem como a transferência de mantença a favor de requerente que tenha sido penalizada no sistema federal de ensino, em questões relativas à educação superior, nos últimos 05 anos, direta ou indiretamente por alguma entidade mantida. Finalmente, no exercício da atividade instrutória ex officio, a Secretaria competente poderá determinar a apresentação de documentos que atestem as reais condições econômicas da entidade que cede a mantença $^{28}$, para obter informações circunstanciadas sobre a situação de autofinanciamento da instituição, cumprindo o disposto no art. $7^{\circ}$, inciso III, LDB, e objetivando a preservação da atividade educacional e do interesse dos discentes.

\section{CREDENCIAMENTO ESPECÍFICO PARA EDUCAÇÃO À DISTÂNCIA}

O credenciamento específico para oferta de educação à distância está previsto nos arts. $9^{\circ}$ e seguintes, do Decreto $n^{\circ} 5.622 / 05$, bem como no art. 26 Decreto $n^{\circ} 5.773 / 06$. O pedido observará os pressupostos relacionados com o credenciamento de IES, sendo instruído pela SESu ou pela SETEC, ante a natureza do curso, com a participação da Secretaria de Educação a Distância (SEED). O requerimento deste tipo de credenciamento também deverá estar munido de comprovante de recolhimento da taxa de avaliação in loco, acrescido dos documentos mencionados no art. 12 Decreto $\mathrm{n}^{\circ}$ 5.622/05, cujo PPC respeitará os elementos do art. 13 do mesmo decreto. Destaca-se que as disposições gerais sobre credenciamento e recredenciamento de IES se aplicam à educação à distância. Portanto, é pacífica a possibilidade de existirem cursos superiores nesta modalidade (seqüenciais, de graduação, de especialização, de mestrado e de doutorado), segundo o art. $2^{\circ}$, inciso V, alíneas "a", "b", "c", "d" e "e", Decreto $\mathrm{n}^{\mathrm{o}}$ 5.622/05, competindo exclusivamente ao Ministro de Estado da

\footnotetext{
${ }^{27}$ Leia-se contrato ou documento de negócio jurídico, que cumpra todos os elementos e requisitos da Lei civil.

${ }^{28}$ Como exemplo, o $\S 5^{\circ}$, do art. 25 Decreto $\mathrm{n}^{\circ} 5.773 / 06$, cita as certidões de regularidade fiscal, além de outros documentos que a Secretaria pertinente entender convenientes. Trata-se de rol enunciativo que não afasta o poder discricionário da Secretaria de Educação competente.
} 
Educação a promoção dos atos de credenciamento de IES para o oferecimento de cursos e

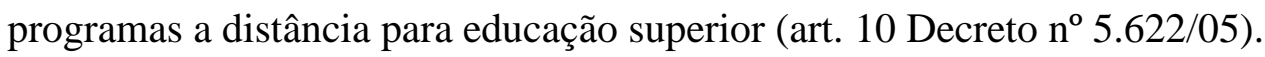

Assim, cumpriu-se integralmente a norma especial constante no art. 80, $\S 1^{\circ}$, LDB, que condiciona a oferta de educação superior à distância ao credenciamento prévio e específico da União, em virtude de sua característica transgeográfica e de sua índole nacional. Da mesma maneira, parte do art. 11 Decreto $n^{\circ} 5.622 / 05^{29}$, já que somente as regras para produção, controle, avaliação, autorização e reconhecimento de cursos de educação à distância são atribuições dos respectivos sistemas de ensino, preservando sempre a cooperação entre sistemas diversos, em conformidade com os arts. 80, § $3^{\circ}$, LDB, 15 e 17 Decreto $n^{\circ} 5.622 / 05$. Nesse ponto, salienta-se que os $\S \S$, do art. 11 Decreto $n^{\circ} 5.622 / 05$, mantêm o credenciamento pelo MEC, na hipótese dos cursos à distância, no nível básico (nas modalidades de educação de jovens e adultos, especial e profissional), alcançarem outros Estados membros, diferentes da unidade federativa sede, instituindo uma colaboração obrigatória entre os Conselhos de Educação dos sistemas envolvidos, mediante regulamentação por ato administrativo normativo.

Portanto, houve a inserção do credenciamento do ensino básico à distância no sistema estadual, quando ofertado apenas no âmbito da respectiva unidade federativa, o que enseja a ilegalidade parcial do art. 11 Decreto $\mathrm{n}^{\circ}$ 5.622/05, para os cursos à distância deste nível, nas modalidades de educação de jovens e adultos, especial e profissional, ante a afronta direta ao art. $80, \S 1^{\circ}$, LDB, e a contradição indireta aos arts. $5^{\circ}$, inciso II, 22, inciso XXIV, 59, 61 e seguintes, CR/88. Com isso, o art. 11 Decreto $\mathrm{n}^{\circ}$ 5.622/05 exorbitou, parcialmente, o poder regulamentar ${ }^{30}$, ao inserir o credenciamento do ensino básico à distância, nas modalidades

\footnotetext{
${ }^{29}$ Art. 11 Decreto $\mathrm{n}^{\mathrm{o}}$ 5.622/05 - Compete às autoridades dos sistemas de ensino estadual e do Distrito Federal promover os atos de credenciamento de instituições para oferta de cursos a distância no nível básico e, no âmbito da respectiva unidade da Federação, nas modalidades de:

I - educação de jovens e adultos;

II - educação especial; e

III - educação profissional.

$\S 1^{\text {o }}$ Para atuar fora da unidade da Federação em que estiver sediada, a instituição deverá solicitar credenciamento junto ao Ministério da Educação.

$\S 2^{\circ} \mathrm{O}$ credenciamento institucional previsto no $\S 1^{\circ}$ será realizado em regime de colaboração e cooperação com os órgãos normativos dos sistemas de ensino envolvidos.

$\S 3^{\circ}$ Caberá ao órgão responsável pela educação a distância no Ministério da Educação, no prazo de cento e oitenta dias, contados da publicação deste Decreto, coordenar os demais órgãos do Ministério e dos sistemas de ensino para editar as normas complementares a este Decreto, para a implementação do disposto nos $\S \S 1^{\circ} \mathrm{e}$ $2^{\circ}$.

${ }^{30}$ Sobre o âmbito e limites da função regulamentar, por meio de atos administrativos normativos, destaca-se brevemente que [...] "tais atos, conquanto normalmente estabeleçam regras gerais e abstratas de conduta, não são leis em sentido formal. São leis apenas em sentido material, vale dizer, provimentos executivos com conteúdo de lei, com matéria de lei. Esses atos, por serem gerais e abstratos, têm a mesma normatividade da lei e a ela se equiparam para fins de controle judicial, mas, quando, sob a aparência de norma, individualizam situações e impõem encargos específicos a administrados, são considerados de efeitos concretos e podem ser
} 
acima indicadas e quando fornecido por instituições escolares estaduais, municipais ou privadas, no sistema estadual de ensino e não no federal ${ }^{31}$, negando vigência à legislação federal que fixa a competência exclusiva do Ministro da Educação para o credenciamento de instituição de educação à distância, ao princípio da anterioridade da lei (não do ato administrativo normativo) e a competência originária do Poder Legislativo para editar leis.

Existe, ainda, a possibilidade, contida no art. $9^{\circ}$ Decreto $\mathrm{n}^{\circ} 5.622 / 05$, do ato de credenciamento para o oferecimento de cursos e programas à distância serem destinados às instituições de ensino, públicas ou privadas, em qualquer nível. Não por demais, as instituições de pesquisa científica e tecnológica, com notória e relevante produção acadêmica investigativa, poderão solicitar credenciamento para a oferta de cursos ou programas à distância de especialização, mestrado, doutorado e educação profissional tecnológica de pósgraduação.

O Decreto $\mathrm{n}^{\circ} 5.773 / 06$ foi fiel ao art. 14 Decreto $\mathrm{n}^{\circ} 5.622 / 05$, já que formulou disposições semelhantes quanto à duração do credenciamento $\left(\S 4^{\circ}\right.$, do art. 13 Decreto $\mathrm{n}^{\circ}$ 5.773/06), quanto ao prazo para início das atividades da IES credenciada e a caducidade do ato autorizativo (art. 68 Decreto $\mathrm{n}^{\mathrm{o}}$ 5.773/06), quanto ao prazo para solicitação do recredenciamento (arts. $10, \S 3^{\circ}, 20$, Decreto $n^{\circ} 5.773 / 06$ ) e quanto à utilização dos resultados do SINAES nos procedimentos de mesmas índole (art. 22, caput e $\S 1^{\circ}$, Decreto $\mathrm{n}^{\circ} 5.773 / 06$ ).

No entanto, o art. $15, \S \S$, Decreto $\mathrm{n}^{\mathrm{o}} 5.622 / 05$ estabelece, como peculiaridades, que o credenciamento de IES para oferta de cursos ou programas a distância fixará a abrangência de sua atuação no território nacional, em função da capacidade institucional. Além disso, o requerimento de ampliação da área de abrangência da IES, credenciada para oferecimento de cursos superiores à distância, deverá ser realizada perante a SESu ou a SETEC, conforme o caso, no MEC, mediante intervenção da SEED. Na hipótese de indeferimento parcial de requerimento, a instituição poderá interpor recurso à CES do CNE. Destaca-se que o SINAES será aplicado integralmente à educação superior à distância (art. 16 Decreto $\mathrm{n}^{\circ}$ 5.622/05), empregando seus instrumentos, formas e critérios avaliativos. Caso a avaliação no recredenciamento de IES que fornece curso superior à distância seja insatisfatória, o art. 17 Decreto $n^{\circ} 5.622 / 05$ formula medidas administrativas genéricas a serem adotadas, que não são incompatíveis com as existentes nos arts. 10, Lei $n^{\circ} 10.861 / 04,23,60,61$ e 63, Decreto $n^{\circ}$

atacados e invalidados direta e indiretamente por via judicial comum, ou por mandado de segurança, se lesivos de direito individual líquido e certo" (MEIRELLES, 1997, p. 161-162).

${ }^{31}$ Pelo art. 80, $\S 1^{\circ}$, LDB, o credenciamento de qualquer instituição que forneça curso a distância, em todos os níveis e modalidades, será feito exclusivamente pela União, por meio de seu MEC. Desse modo, para evitar 
5.773/06, devendo ser celebrado protocolo de compromisso. Na eventualidade de desrespeito ao protocolo, também será instaurado processo administrativo, para cassar a autorização de funcionamento da IES (arts. 10, $\S 2^{\circ}$, inciso II, $\S 3^{\circ}$, Lei $n^{\circ} 10.861 / 04$; e, 63, inciso II, Decreto $\left.\mathrm{n}^{\mathrm{o}} 5.773 / 06\right)$, suspendendo-se o curso do pedido de recredenciamento, até o encerramento do citado processo (art. 23 Decreto $\mathrm{n}^{\circ} 5.773 / 06$ ).

\section{CONSIDERAÇÕES FINAIS}

Quanto à natureza institucional ou administrativa, as IES podem se classificar como universidades, centros universitários, faculdades integradas ou estabelecimentos isolados, em conformidade com os diversos âmbitos de especialização autorizados pelo art. 45 LDB.

Dessa forma, os variados níveis de abrangência, segundo a organização e prerrogativas acadêmicas das instituições, mencionados nos arts. 45 LDB, 12 e 13 Decreto $n^{\circ}$ 5.773/06, são outorgados pelos atos autorizativos, em função da existência ou não da associação entre ensino e pesquisa.

Nesse ínterim, os arts. 13, Decreto $n^{\circ} 5.773 / 06$, e $2^{\circ}, \S 3^{\circ}$, Decreto $n^{\circ} 5.786 / 06$ fixam que as IES somente poderão ser credenciadas, pela primeira vez, como faculdades. Ademais, as universidades ou centros universitários terão credenciamento especial, convertendo o credenciamento ordinário das faculdades em funcionamento, desde que possuam padrão de qualidade satisfatório, ante uma avaliação positiva no SINAES, o que não foi determinado pelo art. 16, inciso II, LDB, violando os arts. 84, inciso IV, $5^{\circ}$, inciso II, 22, inciso XXIV e seu parágrafo único, 59, 61 e seguintes, 206, inciso III, todos da CR/88.

Por sua vez, o art. 10, caput e $\S \S$, Decreto $\mathrm{n}^{\circ} 5.773 / 06$, determina que o ato autorizativo do Poder Público é indispensável ao funcionamento de IES e ao oferecimento de curso de nível superior, cujas modalidades são: autorização, reconhecimento e renovação de reconhecimento de cursos superiores; credenciamento e recredenciamento de instituições; além de suas eventuais e respectivas alterações.

A LDB foi rigorosa em matéria de autorização e reconhecimento de cursos. Nos termos do art. 46 e $\S \S, \mathrm{LDB}$, os prazos de ambos os institutos são limitados e dependem de prévia avaliação para renovação que, dependendo do resultado, pode ensejar a desativação de cursos ou habilitações, a eventual intervenção na IES, a suspensão de prerrogativas da autonomia, para instituições não universitárias (art. 207 CR/88), ou o descredenciamento. Quando se tratar de IES pública, o Poder Executivo, responsável pela manutenção da mesma, 
deverá acompanhar o processo de saneamento, fornecendo subsídios financeiros adicionais para a superação das deficiências apontadas, se necessários. Caso a última instituição precise ser sancionada provisoriamente, tal medida deverá ser imposta por lei, em virtude do princípio do paralelismo das formas.

Os referidos atos autorizativos de cursos superiores são atos administrativos unilaterais, vinculados, posto que se forem cumpridas todas as condições legais, em processo regular de avaliação (art. 46, caput, LDB), o Executivo é obrigado a autorizar ou reconhecer os cursos superiores. Destaca-se que nos procedimentos de autorização e reconhecimento devem-se respeitar os princípios constitucionais do contraditório e da ampla defesa (art. $5^{\circ}$, inciso LV, CR/88), sem prejuízo do da inafastabilidade do controle jurisdicional (art. $5^{\circ}$, inciso $\mathrm{XXXV}, \mathrm{CR} / 88$ ), por serem direitos fundamentais garantidos a todos no Brasil, sejam pessoas físicas ou jurídicas, de direito público ou privado. Por tais motivos, o Ministro da Educação só pode homologar os pareceres sobre as solicitações de autorização e reconhecimento, após análise de eventual recurso administrativo, interposto ao órgão competente, para seu conhecimento. A natureza dos mencionados atos são diferentes, já que a autorização classifica-se como ato constitutivo na medida que modifica uma situação jurídica, produzindo efeitos a partir do momento em que é expedida. Por outro lado, o reconhecimento classifica-se como ato declaratório, por simplesmente reconhecer uma situação jurídica preexistente, ensejando efeitos retroativos à data da autorização. Passados os prazos de autorização e reconhecimento de cursos, terminam as qualificações que concedem o direito às IES em abrir vagas em processo seletivo de discentes e emitir diplomas, respectivamente, conforme o art. 48 LDB. Na hipótese de não renovação, sempre precedida de processo administrativo (art. $5^{\circ}$, inciso LIV, CR/88), sanciona-se a IES.

É sabido que a educação superior, a exemplo dos demais níveis de ensino, é livre a iniciativa privada, desde que sejam respeitadas as normas gerais educacionais e que haja autorização e avaliações qualitativas por parte do Poder Público, nos termos dos arts. 209, incisos I e II, CR/88 e $9^{\circ}$, Decreto $\mathrm{n}^{\circ}$ 5.773/06. Com isso, o credenciamento e o recredenciamento de IES são modalidades de atos administrativos autorizativos, segundo o $\S$ $1^{\circ}$, art. 10 Decreto $n^{\circ} 5.773 / 06$, e manifestam, expressa e formalmente, os diversos níveis de abrangência das instituições. Tratam-se de atos administrativos unilaterais, constitutivos e vinculados, renovados periodicamente e emitidos pelo Ministro de Estado da Educação ou pelos Secretários Estaduais de Educação, quando a IES integre o sistema estadual de ensino, que comprovam a qualidade mínima do ensino ministrado em tais instituições e o cumprimento dos requisitos legais para o funcionamento das mesmas.

Revista da Faculdade Mineira de Direito, v.12, n. 23, jan./jun. 2011 - ISSN 1808-9429. 
Por meio do credenciamento e de sua renovação, a Administração Pública exerce competência avaliativa sobre seu sistema de ensino, analisando o desempenho das IES, a qualidade do ensino fornecido nos respectivos cursos, dos seus programas de pós-graduação stricto sensu, da investigação e produção académica lá realizada, em conformidade com indicadores previamente estabelecidos.

Os institutos em questão e as disposições infraconstitucionais supramencionadas possuem respaldo constitucional nos arts. 206, inciso VII, e 209, inciso II, CR/88 (princípio da garantia do padrão de qualidade), o que, por si, parece justificar e amparar a existência do sistema nacional de avaliação atual. Todavia, essa alegação merece maior aprofundamento e outros estudos específicos.

Essa afirmativa não se aplica à inserção do credenciamento do ensino básico à distância no sistema estadual, quando ofertado apenas no âmbito da respectiva unidade federativa. $\mathrm{O}$ art. 11, do Decreto $\mathrm{n}^{\circ}$ 5.622/05, sobre os cursos à distância deste nível, nas modalidades de educação de jovens e adultos, especial e profissional, é ilegal ante a afronta direta ao art. 80, $\S 1^{\circ}, \mathrm{LDB}$, e a contradição indireta aos arts. $5^{\circ}$, inciso II, 22, inciso XXIV, 59, 61 e seguintes, CR/88. Com isso, o art. 11, do Decreto $\mathrm{n}^{\mathrm{o}}$ 5.622/05, exorbitou, parcialmente, o poder regulamentar, ao inserir o credenciamento do ensino básico à distância, nas modalidades acima indicadas e quando fornecido por instituições escolares estaduais, municipais ou privadas, no sistema estadual de ensino e não no federal, negando vigência à legislação federal que fixa a competência exclusiva do Ministro da Educação para o credenciamento de instituição de educação à distância, ao princípio da anterioridade da lei (não do ato administrativo normativo) e a competência originária do Poder Legislativo para editar leis.

Finalmente, para solucionar tal ilegalidade, o credenciamento de qualquer instituição que forneça curso a distância, em todos os níveis e modalidades, deverá ser feito exclusivamente pela União, por meio de seu MEC, para evitar discussões judiciais, independentemente do art. 11, caput, Decreto $n^{\circ}$ 5.622/05, e em aplicação integral ao art. 80, $\S 1^{\mathrm{o}}, \mathrm{LDB}$.

\begin{abstract}
Is desired, with the present work, the study of the administrative acts and its respective procedures of authorization of superior courses and Institutions of Higher Education (IES), of the federal system. One is a preponderantly theoretical-documentary work, in a dogmatic perspective, employee as form of analysis of the results. Like conclusion, one has appeared the legal nature of the administrative acts of authorization, the obligation of observance to the
\end{abstract}


process constitutional principles in the administrative procedures, the intimate relation between the first and National System of Higher Educational Evaluation (SINAES), in addition to the partial illegality of article 11 of the Decree $n^{\circ} 5.622 / 05$.

Keywords: Educational public policies; Evaluation of systems of education; Administrative acts of authorization of institutions of higher education.

\section{Resumén}

Se desea, con el presente trabajo, el estudio de los actos administrativos y sus respectivos procedimientos de autorización de cursos superiores y de Instituciones de Enseñanza Superior (IES), del sistema federal de enseñanza. Se trata de un trabajo preponderantemente teóricodocumental, en una perspectiva dogmática, empleada como forma de análisis de los resultados. Como conclusión, se ha presentado la naturaleza jurídica de los actos administrativos de autorización, la obligación de observancia a los principios constitucionales procesales en los procedimientos administrativos, la intima relación entre los primeros y el Sistema Nacional de Evaluación de la Enseñanza Superior (SINAES), además de la ilegalidad parcial del artículo 11 del Decreto n ${ }^{\circ}$ 5.622/05.

Palabras-clave: Políticas públicas educacionales. Evaluación de sistemas de enseñanza. Actos administrativos de autorización de instituciones de enseñanza superior.

\section{REFERÊNCIAS}

BRASIL. Ministério da Educação. Instituto Nacional de Estudos e Pesquisas Educacionais Anísio Teixeira. SINAES - Sistema Nacional de Avaliação da Educação Superior: da concepção à regulamentação. 4. ed. Brasília: INEP, 2007. 224p.

BRASIL. Ministério da Educação. Ministério da Fazenda. Ministério da Previdência e Assistência Social. Ministério da Ciência e Tecnologia. Projeto de Lei de Reforma Universitária. In: BRASIL. Ministério da Educação. Ministério da Fazenda. Ministério da Previdência e Assistência Social. Ministério da Ciência e Tecnologia. E.M.I no 015/MEC/MF/MP/MCT. Brasília: MEC; MF; MP; MCT, 2006. 23p. Disponível em: $<$ http://www.sintufsc.ufsc.br/noticias_2006/0619_reforma.pdf >. Acesso em: 29/01/2008.

BRASIL. Superior Tribunal de Justiça. Mandado de Segurança nº 4831/DF. EMENTA: Constitucional. Mandado de segurança. Principio do contraditório aplicável ao processo administrativo. Concessão da segurança. A Lei n ${ }^{\circ}$ 9.131, de 1995 , ao enumerar as atribuições da Câmara de Educação Superior, instituiu o recurso contra seus pareceres a ser julgado pelo Conselho Pleno. O pedido de reconhecimento de curso de graduação, em face da legislação de regência, não pode ser homologado pelo Ministério da Educação, antes que o Conselho Pleno aprecie o recurso interposto, in opportuno tempore, pelo interessado. No sistema jurídicoconstitucional vigente, a instituição de decisão irrecorrível, ainda que na esfera administrativa, é inconciliável com o principio constitucional da ampla defesa que, por si, pressupõe mais de um grau de jurisdição. Segurança concedida. Decisão unânime. Rel. Min. Demócrito Reinaldo, Brasília, 23 abr. 1997. Diário de Justiça da União, Brasília, 16 jun. 1997. Seção 01, p. 27308. Disponível em: <http://www.stj.gov.br>. Acesso em: 18/03/2008. 
CAMPOS, Regina; MACHADO, Lucília. Universidade. In: FIDALGO, Fernando;

MACHADO, Lucília (Ed.). Dicionário da educação profissional. Belo Horizonte: Núcleo de Estudos sobre Trabalho e Educação, 2000. Voz, p. 350-351.

CAUPERS, João. Introdução ao direito administrativo. 5. ed. Lisboa: Âncora Editora, 2000. 328p.

CUNHA, Luiz Antônio. Ensino superior e universidade no Brasil. In: LOPES, Eliane Marta Teixeira; FARIA FILHO, Luciano Mendes; VEIGA, Cynthia Greive (Org.). 500 anos de educação no Brasil. 3. ed. Belo Horizonte: Autêntica, 2003. p. 151-204.

DI PIETRO, Maria Sylvia Zanella. Direito administrativo. 17. ed. São Paulo: Atlas, 2004. $751 \mathrm{p}$.

MARINONI, Luiz Guilherme; ARENHART, Sérgio Cruz. Curso de processo civil: processo de conhecimento. 6. ed. São Paulo: Revista dos Tribunais, 2007. v. 2. 816p.

MARTINS, Carlos Benedito de Campos. Ensino pago: um retrato sem retoques. São Paulo: Global Editora, 1981. 212p.

MEIRELLES, Hely Lopes. Direito administrativo brasileiro. 22. ed. São Paulo: Malheiros Editores, 1997. 733p.

MINTO, Lalo Watanabe. As reformas do ensino superior no Brasil: o público e o privado em questão. Campinas: Autores Associados, 2006. 320p.

MURIEL, Roberta. Plano de desenvolvimento institucional - PDI: análise do processo de implantação. Brasil: Editora Hoper, 2006. 184p.

NUNES, Pedro dos Reis. De ofício. In: NUNES, Pedro dos Reis. Dicionário de tecnologia jurídica. 12. ed. Rio de Janeiro: Freitas Bastos, 1993. p. 306.

RANIERI, Nina Beatriz. Educação superior, direito e estado: na Lei de Diretrizes e Bases (Lei nº 9.394/96). São Paulo: Editora da Universidade de São Paulo; FAPESP, 2000. 408p.

RIBEIRO, Maria das Graças M. Educação superior brasileira: reforma e diversificação institucional. Bragança Paulista: EDUSF, 2002. 210p.

SAMPAIO, Helena. Ensino superior no Brasil: o setor privado. São Paulo: Hucitec; FAPESP, 2000. 408p.

SOUSA, José Vieira de. O ensino superior privado no Distrito Federal: uma análise de sua recente expansão (1995-2001). 2003. 279f. Tese (Doutorado em Sociologia) - Universidade de Brasília.

THEODORO JÚNIOR, Humberto. Curso de direito processual civil: teoria geral do direito processual civil e processo de conhecimento. 47. ed. Rio de Janeiro: Forense, 2007. v. 1. $862 \mathrm{p}$.

TRAMONTIN, Raulino; BRAGA, Ronald. O Ensino superior particular no Brasil: traços de um perfil. In: MENDES, Candido; CASTRO, Cláudio de Moura (Orgs.). Qualidade, 
expansão e financiamento do ensino superior privado. Rio de Janeiro: EDUCAM; ABM, 1984. Cap. 1, p. 19-50.

TRIGUEIRO, Michelangelo Giotto Santoro. Ensino superior privado no Brasil. Brasília: Paralelo 15; 2000. 128p. 